\title{
Comparative Study on Plastic Materials as a New Source of Energy
}

\author{
MARIUS CONSTANTINESCU ${ }^{1,2}$, FELICIA BUCURA ${ }^{1}$, ROXANA-ELENA IONETE ${ }^{1}$, VIOLETA-CARO LINA NICULESCU ${ }^{1}$, \\ EUSEBIU ILARIAN IONETE ${ }^{1}$, ANCA ZAHARIOIU ${ }^{1,2}$, SIMONA OANCEA ${ }^{2}$, MARIUS GHEORGHE MIRICIOIU ${ }^{1 *}$ \\ ${ }^{1}$ National Research and Development Institute for Cryogenics and Isotopic Technologies- ICSI Rm. Valcea, $4^{\text {th }}$ Uzinei Str.,240050, \\ Rm. Valcea, Romania \\ 2Lucian Blaga University of Sibiu, 10 Victoriei Blvd, 550024, Sibiu, Romania
}

\begin{abstract}
The pyrolysis can be an attractive way to reduce the plastic waste and, in the same time, to obtain alternative conventional fuels. In this respect, four polymers (low-density polyethylene, high-density polyethylene, propylene and polystyrene) were used in the pyrolysis process. The experiments were carried out by using an in-house plant, which allowed a maximum test temperature of $450^{\circ} \mathrm{C}$. The product oil and the derived gas from the pyrolysis process were evaluated using different techniques, such as elemental analysis (EA), calorimetry, gas chromatography (GC), gas chromatography coupled with mass spectrometry (GC-MS). Furthermore, for a comparative study two catalysts, zeolite and lignite, were also used for the pyrolysis process, in order to observe their influences on the final products. The higher heating value obtained for the oil was in the 40.17-45.35 MJ/kg range, acceptable for the use of these oil as an alternative fuel for diesel engine. Also, the sulphur content from the obtained oil does not cause environment problems, being lower than the allowed limits (10 $\mathrm{mg} / \mathrm{L}$ ). In addition, the pyrolysis derived gas was rich in hydrocarbons, conducting to a high calorific value, in the $73.42-121.18 \mathrm{MJ} / \mathrm{kg}$ range.
\end{abstract}

Keywords: catalyst, lignite, plastic, pyrolysis, waste

Nowadays, with a world production of 335 million tonnes in 2016, the plastics play an important role in various areas such as, food, chemical, construction, automotive, agriculture, electronic and fashion, due to their properties: easier processability, durability or corrosion resistance. The last two properties turn the advantages of these materials into a serious environmental problem, because the plastic waste accumulation and their low degradability property resulted in the occupation of a large storage area [1,2].

In Europe, comparing with the statistics reported in 2012, in 2016 the plastic waste amount increased with approximately 2 million tons, from 25 million tons, while the percentage sent to the landfill decreased from $38 \%$ to $27.3 \%$. In the same time, in the case of recycle and energy recovery the statistic was better, the percentages increasing from $26 \%$ and $36 \%$ to $31.1 \%$ and $41.6 \%$, respectively $[2,3]$.

The incineration is not an environment solution to decrease the plastic waste quantity, due to carbon dioxide release into atmosphere, but the pyrolysis can be. Many researchers turned their attention to waste plastic pyrolysis, highlighting the advantages of this process by converting the waste into high calorific power oil or gaseous products [4-8]. Their studies were focused on the pyrolysis of $i$ ) virgin plastic materials, ii) plastic wastes and co-pyrolysis of plastic-wood composite (w oody biomass), using different reactor configurations [3, 9-15]. The obtained oil products can be comparable with petroleum [16], in terms of heat value and emission factor, thus being tested in diesel engines. Furthermore, the by-product gas presents also a high heat value and the residue is obtained in low quantity. A serious drawback in the plastics pyrolysis is the requirement of high temperature, but this can be an energetically sustainable process considering the high heat values of the oil and gas products $[17,18]$.

Various parameters, such as temperature, time and catalyst, influence the quality of gaseous and liquid products resulted from the pyrolysis process [4-8].
It was demonstrated that the most important pyrolysis parameter, the temperature, influences the properties of the obtained oil and gaseous products, due to thermally degrading polymer chain [8]. Thus, at a temperature of about $600{ }^{\circ} \mathrm{C}$ it was obtained a liquid with higher content of aromatic hydrocarbons than at a temperature of about $450^{\circ} \mathrm{C}$. Also, it was evidenced an optimum reaction time interval, between 15 and $30 \mathrm{~min}$, when a total conversion is achieved [8]. The use of various catalysts is expected to reduce the required temperature of plastic degradation but, on the other hand, their use can increase the process cost. Therefore, the introduction of a cheaper catalyst into the process (found in abundance in nature, such as natural zeolite), as an alternative for the commercial catalysts (such as zeolite-Y, ZSM5, Al-MCM-41) can be the key to reduce the costs [19-21].

Taking into account all the above-mentioned aspects, this study focused on the investigation of the pyrolysis process of virgin plastics (obtained from low-density polyethylene, high-density polyethylene, polypropylene, and polystyrene) with and without catalysts (lignite and zeolite), in order to observe the difference of pyrolysis products.

\section{Experimental part}

Materials and methods

The used polymers were commercially available products, such as: low-density polyethylene (LDPE) and polypropylene (PP) were procured from SABIC (Riyadh, Saudi Arabia) and polystyrene (PS), high-density polyethylene (HDPE) were purchased from Versalis S.p.A (Santo Donato Milanese, Italy).

One of the used catalysts was lignite, due to the high content of lignin. This was purchased from a local mine (Berbesti mine, Valcea county, Romania). Another type of catalyst, the LMS (Linde Molecular Sieves) zeolite, was obtained from Linde Romania (Bucharest, Romania).

* email: marius.miricioiu@icsi.ro; Phone: 0040746916354 

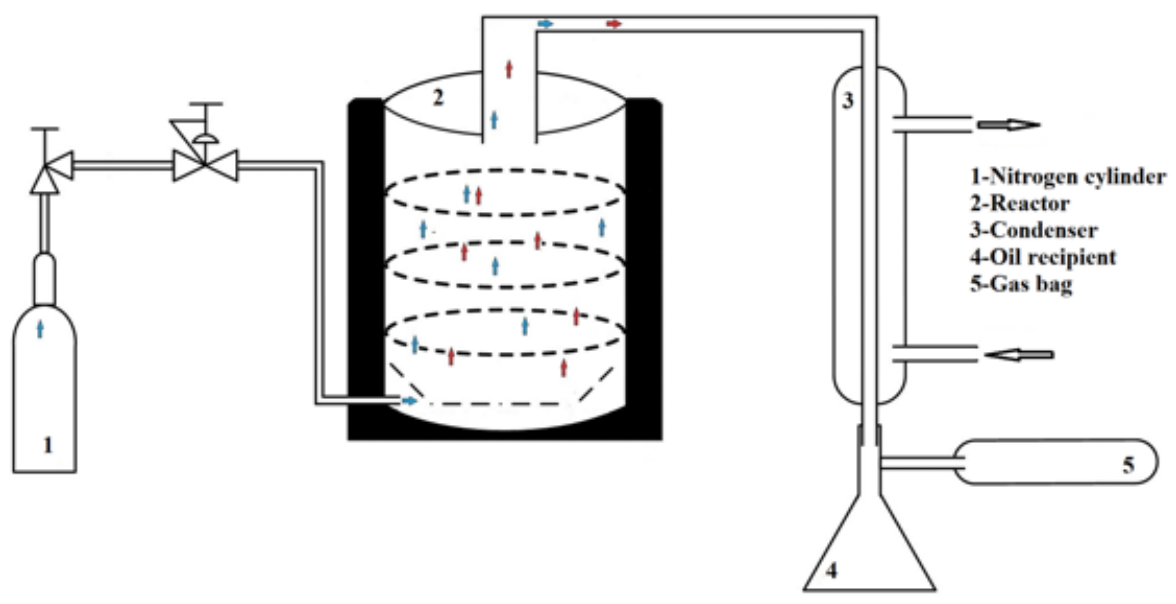

Fig. 1. Pyrolysis experimental setup

High purity nitrogen (99.999\%Vol) was purchased from SIAD Romania (Bucharest, Romania).

The pyrolysis products were examined using an EA 2000 Flash elemental analyser (Thermo Scientific, Waltham, MA, USA) in order to obtain information about the gaseous emissions resulted after the combustion of liquid oil product. The analyser had a thermal conductivity detector (TCD) and two chromatographic columns (SM5A and Porapack Q) purchased from Sigma Aldrich (Steinheim, Germany).

The heat value, the most important quality characteristic, was established through an IKA 5000 calorimeter (IKA, Staufen im Breisgau, Germany).

For the analysis of non-condensable gases, a Varian CP 3800 gas chromatograph (Varian Instruments, Palo Alto, CA, USA) was used. It was equipped with thermal conductivity and flame ionization detectors and three columns, such as CP-Al $\mathrm{O}_{2} / \mathrm{KCl}(25 \mathrm{~m} \times 0.32 \mathrm{~mm}$ internal diameter), CP-PoraBOND Q-HT (27.5 $\mathrm{m} \times 0.32 \mathrm{~mm}$ internal diameter), CP-Molsieve $5 \AA$ ( $50 \mathrm{~m} \times 0.53 \mathrm{~mm}$ internal diameter) (Agilent Technologies Inc., Santa Clara, CA, USA). The chromatographic method was previously developed [22].

Furthermore, a Varian 450 gas chromatograph (Varian Instruments, Palo Alto, CA, USA) coupled with a Varian 240 mass spectrometer (Varian Instruments, Palo Alto, CA, USA) was used for the qualitative analysis of the pyrolysis liquid oil. The chromatograph was equipped with a Thermo Scientific TG-WAXMS capillary column $(60 \mathrm{~m} \times 0.32 \mathrm{~mm} \times$ $0.25 \mu \mathrm{m}$ ) (Thermo Scientific, Waltham, MA, USA) for the separation of oil compounds and a splitinjection valve (1:10 split ratio) heated at $150^{\circ} \mathrm{C}$ for volatile compounds. Also, this chromatographic method was described in a previous work [23].

\section{Experiemhtal setup}

The pyrolysis process was carried out using the experimental setup presented in figure 1. The installation consists in a pyrolysis reactor made from stainless steel with an internal diameter of $100 \mathrm{~mm}$ and a height of 450 $\mathrm{mm}$. Inside the reactor there are placed two stainless-steel supports, one for the tested materials and the second one for the catalyst. The reactor is isolated with basaltic wool to maintain a constant temperature and it is thermostated through a ceramic bracelet that ensure a temperature up to $450^{\circ} \mathrm{C}$. Prior to the experiments, a nitrogen flow of about $100 \mathrm{~mL} / \mathrm{min}$ was provided by a gas cylinder in order to ensure an inert atmosphere.

Also, the reactor is equipped with a water condenser, in order to separate the products into condensable and noncondensable products, which were collected in an oil recipient and a gas bag, respectively.
The tests were performed using, in the first step, the polymers (PP, PS, HDPE and LDPE) without the catalysts. The necessary polymer quantity was $55 \mathrm{~g}$ and the temperature ranged between 24 and $450^{\circ} \mathrm{C}$, with a step increment ratio of $50{ }^{\circ} \mathrm{C} / 5 \mathrm{~min}$. After the maximum temperature was reached, this was held for $30 \mathrm{~min}$.

In the second step, the polymers in presence of catalysts (zeolite or lignite) were used with a 1/10 (zeolite/polymer) ratio, in order to observe the changes in the quality products. The catalysts were placed above the polymer sample in their support to offer time and space for a better interaction. The pyrolysis processes were carried out in the same conditions and every experiment was repeated for 4 times and the results were averaged.

\section{Results and discussions}

The effect of the plastic types and also of the catalyst on the pyrolysis product yields (oil-PPO, gas-PPG and wastePPW) is presented in figure 2. Itcan be seen that the highest liquid fraction was obtained from the PS in the presence of lignite (79\%), followed by pyrolysis without catalyst of PS (76\%), PP (53\%) and LDPE (41\%). On the other hand, the lowest liquid fraction resulted from the LDPE (38\%) and HDPE (40\%) pyrolysis with zeolite.

The addition of the zeolite catalyst conducted to the decrease of the liquid fraction for all the plastic samples, the most noticeable difference being observed for PS pyrolysis. However, there were not observed significant differences once the lignite was used as catalyst.

Liquid oil products obtained from LDPE, HDPE and PP pyrolysis without and with catalysts showed mainly the presence of paraffinic and olefinic groups (fig. 3). The aromatic compounds ratio is insignificant, being in the 6.50 - $10 \%$ range. The catalysts did not significantly influence the oil content of these polymers.

Instead, the PS pyrolysis oil is dominated by aromatic and paraffins compounds, the content of olefins being negligible. The higher ratio of aromatic compounds was due to its high stability and it was found for the PS / Lignite oil $(45.15 \%)$, followed by the PS / Zeolite oil (44.18\%) and the PS oil (42.20\%). Also, in the case of the oil obtained from the PS pyrolysis with catalysts, no changes were noticed.

The data obtained from the elemental and calorimetric analysis of the pyrolysis oil (elemental content, higher heating value - $\mathrm{HHV}$ and emission factor-EF) are presented in table 1[24-26]. The sulphur contents in the samples are below the method quantification limit $(10 \mathrm{mg} / \mathrm{L})$, in this respect, the posibility of sulphur compounds formation is very reduced, making the pyrolysis oil environmental friendly. Also, the nitrogen content is very low, and it was slightly influenced by the catalyst presence. On the other 


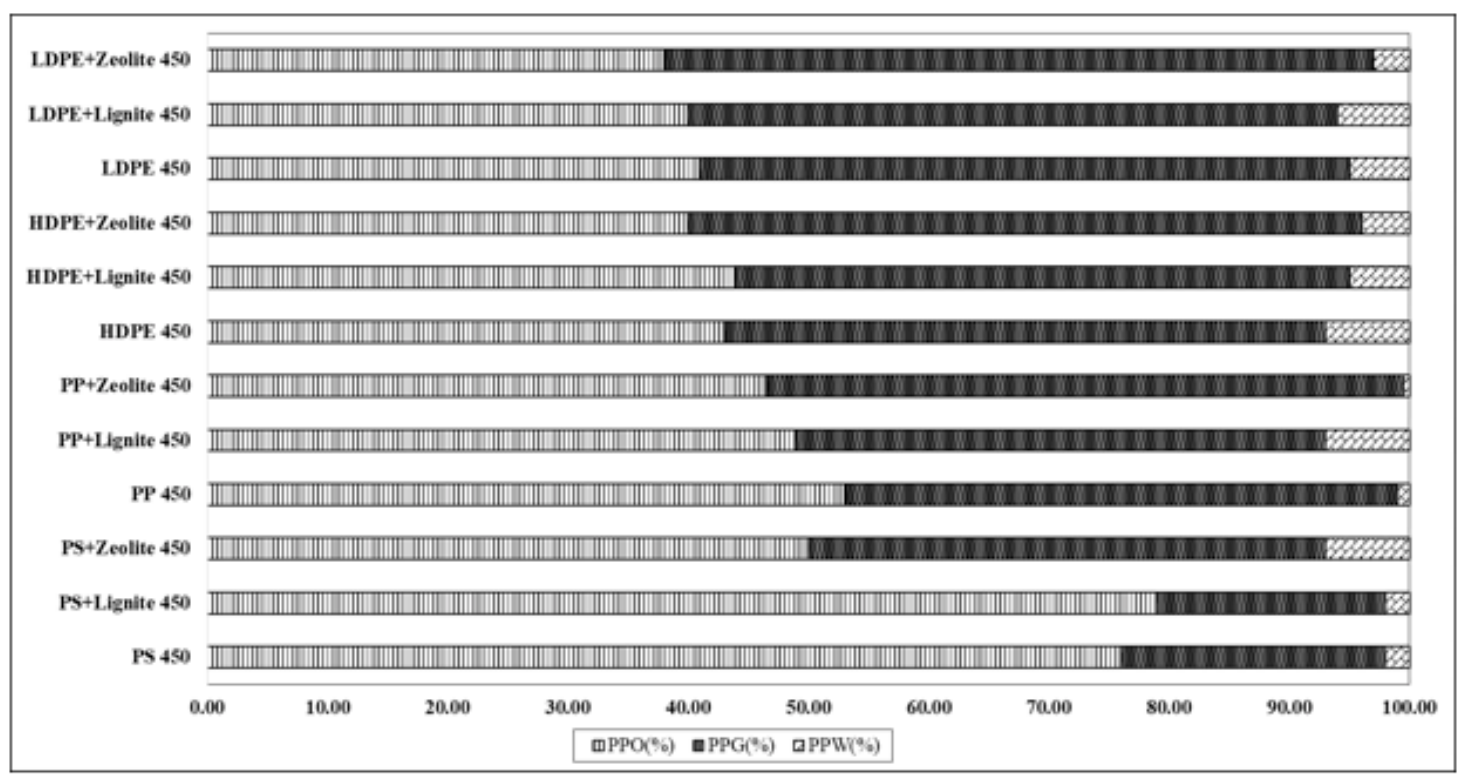

Fig. 2. Effects of the plastic type and catalyst on the product yields

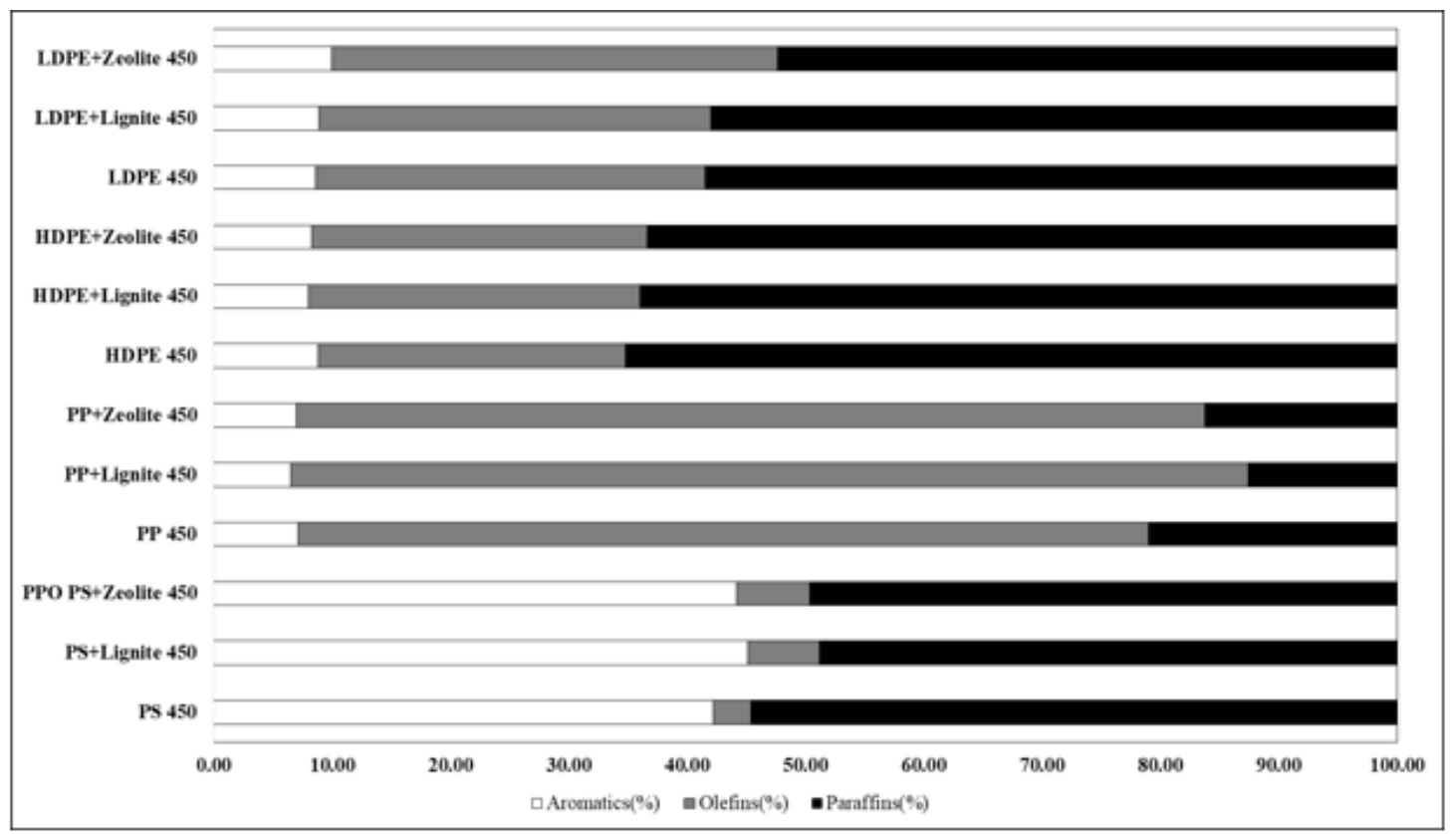

Fig. 3. Comparison of volume fraction obtained using lignite and zeolite catalysts

hand, the highest contents of carbon and hydrogen were $87.92 \mathrm{wt} . \%$ and $13.24 \mathrm{wt}$.\% for the oil obtained from PS and HDPE, respectively, without catalysis. The oxygen content was very low in the oil obtained from PS pyrolysis, namely $3.90 \mathrm{wt} . \%$, and it increased to $9.26 \mathrm{wt} . \%$ and 9.09 $w \mathrm{t} . \%$ due to zeolite and lignite, respectively. The highest oxygen content was obtained in PP pyrolytic oil, $19.39 \mathrm{wt} \%$, but the presence of zeolite and lignite conducted to its decerease to $16.07 \mathrm{wt} . \%$ and $13.95 \mathrm{wt} \%$, respectively.

The oil higher heating values (HHVs) were in the 40.17$45.35 \mathrm{MJ} / \mathrm{kg}$ range, showing their potential as an alternative fuel. The zeolite slighty increased the higher heating value of the LDPE pyrolytic oil. Also the same trend was observed in the case of oil obtained from PS pyrolysis with both catalysts.

Noticeable emission factor value was registered for the oil produced from PS. The use of zeolite and lignite conducted to the improvement of its emission factor.

The gas chromatography results for the gas samples are presented in table 2 and table 3 . Furthermore, a typical chromatogram of the obtained PPG from PS pyrolysis is presented in figure 4.
Among the significant quantities of methane, ethane, ethylene, propane, propylene, n-butane, neo-pentane, in the pyrolysis derived gases, there were also presented permanent gases such as hydrogen, carbon monoxide and carbon dioxide (table 2 and table 3 ). The gas composition depended on the composition of the tested material, therefore the styrene and toluene are the main components of PS.

After the identification and quantification of the components from the pyrolysis gases, the higher heating value and the emission factor were calculated and summarized in table 4 [27].

The gases resulted from the pyrolysis process had significant higher heating values. The gas produced from the PS pyrolysis had the highest HHV $\left(121.18 \mathrm{MJ} / \mathrm{m}^{3}\right)$ and the use of lignite in its pyrolysis conducted to the highest EF (123.71 t/TJ).

The use of catalysts conducted to a decrease of the heat value and to an increase of the emission factor, excepting the case of using lignite for PP pyrolysis.

According to the values presented in table 4 , the resulting gas has the potential to be used in the pyrolysis or the turbine process. 


\begin{tabular}{|c|c|c|c|c|c|c|c|}
\hline Feed material* & $\begin{array}{c}\text { N } \\
\text { (wt.\%) }\end{array}$ & $\begin{array}{c}\mathbf{C} \\
\text { (wt.\%) }\end{array}$ & $\begin{array}{c}\mathbf{H} \\
\text { (wt.\%) }\end{array}$ & $\begin{array}{c}\mathbf{S} \\
\text { (wt.\%) }\end{array}$ & $\begin{array}{c}\mathbf{O} \\
\text { (wt.\%) }\end{array}$ & $\begin{array}{c}\text { HHV } \\
\text { (MJ/kg) }\end{array}$ & $\begin{array}{c}\text { EF } \\
\text { (t/TJ) }\end{array}$ \\
\hline HDPE & 0.34 & 80.71 & 13.24 & 0.005 & 5.71 & 44.50 & 67.25 \\
\hline LDPE & 0.46 & 78.69 & 12.93 & 0.005 & 7.915 & 44.22 & 65.98 \\
\hline PP & 0.3 & 68.83 & 11.47 & 0.005 & 19.395 & 44.63 & 57.18 \\
\hline PS & 0.31 & 87.92 & 7.86 & 0.005 & 3.905 & 40.17 & 81.25 \\
\hline HDPE / Zeolite & 0.13 & 71.75 & 11.49 & 0.005 & 16.63 & 44.29 & 60.06 \\
\hline LDPE /Zeolite & 0.26 & 77.47 & 12.85 & 0.005 & 9.415 & 45.35 & 63.32 \\
\hline PP / Zeolite & 0.25 & 71.72 & 11.95 & 0.005 & 16.075 & 43.64 & 60.95 \\
\hline PS / Zeolite & 0.23 & 83.01 & 7.49 & 0.005 & 9.265 & 41.26 & 74.66 \\
\hline HDPE / Lignite & 0.46 & 73.40 & 9.13 & 0.005 & 17.01 & 42.99 & 63.33 \\
\hline LDPE / Lignite & 0.17 & 67.63 & 11.37 & 0.005 & 20.825 & 44.49 & 56.37 \\
\hline PP / Lignite & 0.49 & 76.16 & 9.39 & 0.005 & 13.955 & 42.62 & 66.29 \\
\hline
\end{tabular}

Tabel 1

ELEMENTAL COMPOSITION, HIGHER HEATING VALUE AND EMISSION FACTOR OF PPO

\section{The pyrolysis temperature was $450{ }^{\circ}$ for all feed materials}

\begin{tabular}{|c|c|c|c|c|}
\hline Composition (\%Vol) & HDPE & LDPE & PP & PS \\
\hline Methane & 3.93 & 4.26 & 6.56 & 0.31 \\
\hline Ethylene & 8.83 & 11.07 & 7.25 & 2.09 \\
\hline Ethane & 5.17 & 4.23 & 1.84 & 5.41 \\
\hline Propane & 19.54 & 19.32 & 4.53 & 1.77 \\
\hline Propylene & 20.03 & 17.20 & 43.03 & 3.79 \\
\hline i-Butane & 0.15 & 0.23 & 0.41 & 0.10 \\
\hline n-Butane & 12.17 & 13.97 & 1.75 & 1.50 \\
\hline neo-Pentane & 10.94 & 13.79 & 10.72 & 0.58 \\
\hline i-Pentane & 0.24 & - & - & 1.68 \\
\hline n-Pentane & 3.74 & 0.24 & 19.91 & 2.95 \\
\hline n-Hexane & 1.42 & 1.26 & 0.22 & 5.55 \\
\hline 2,3-Dimethyllbutane & 4.80 & - & 0.96 & 10.28 \\
\hline 2-Methylhexane & - & - & 0.64 & 4.88 \\
\hline 3-Ethylpentane & - & - & - & - \\
\hline 3-Methylhexane & - & - & - & - \\
\hline 2,2,3-Trimethylbutane & - & - & - & - \\
\hline Methylcyclohexane & 2.04 & - & - & - \\
\hline n-Heptane & - & - & - & - \\
\hline Benzene & - & - & - & - \\
\hline i-Octane & - & - & - & - \\
\hline n-Octane & - & - & - & - \\
\hline Toluene & - & -1.97 & - & 27.11 \\
\hline Styrene & 2.19 & 0.64 & 0.57 & 23.77 \\
\hline Hydrogen & 4.16 & -65 & 1.25 & 0.57 \\
\hline Carbon monoxide & & & & 0.37 \\
\hline Carbon dioxide & -25 & \\
\hline
\end{tabular}

Table 2

COMPOSITION OF DERIVED GAS FROM NON-CATALYSED PLASTIC PYROLYSIS

Table 3

COMPOSITION OF DERIVED GAS FROM CATALYSED PLASTIC PYROLYSIS

\begin{tabular}{|c|c|c|c|c|c|c|c|c|}
\hline Composition \%Vol & $\begin{array}{c}\text { HDPE/ } \\
\text { zeolite }\end{array}$ & $\begin{array}{c}\text { LDPE/ } \\
\text { zeolite }\end{array}$ & $\begin{array}{c}\text { PP/ } \\
\text { zeolite }\end{array}$ & $\begin{array}{c}\text { PS/ } \\
\text { lignite }\end{array}$ & $\begin{array}{c}\text { HDPE/ } \\
\text { lignite }\end{array}$ & $\begin{array}{c}\text { LDPE/ } \\
\text { lignite }\end{array}$ & $\begin{array}{c}\text { PP/ } \\
\text { lignite }\end{array}$ & $\begin{array}{c}\text { PS/ } \\
\text { lignite }\end{array}$ \\
\hline Methane & 3.93 & 6.55 & 6.76 & 0.10 & 14.59 & 7.11 & 18.65 & 3.00 \\
\hline Ethylene & 8.84 & 6.81 & 9.10 & 10.54 & 12.97 & 11.75 & 10.01 & 9.25 \\
\hline Ethane & 5.18 & 13.60 & 1.32 & 1.51 & 24.81 & 6.88 & 11.33 & 17.68 \\
\hline Propane & 19.57 & 19.01 & 8.55 & 1.30 & 5.16 & 18.32 & 3.40 & 1.85 \\
\hline Propylene & 20.07 & 19.93 & 40.65 & 2.15 & 29.37 & 18.83 & 29.59 & 12.43 \\
\hline i-Butane & 0.15 & 0.34 & 0.97 & 1.00 & 0.11 & 0.27 & 0.63 & 0.10 \\
\hline n-Butane & 12.19 & 10.83 & 2.37 & 2.41 & 1.63 & 10.20 & 0.34 & 0.46 \\
\hline neo-Pentane & 10.95 & 7.73 & 11.94 & 1.70 & 0.07 & 11.21 & 16.21 & 2.64 \\
\hline i-Pentane & 0.24 & 0.01 & 0.20 & 0.27 & 0.02 & 1.01 & 2.31 & 0.05 \\
\hline n-Pentane & 3.75 & 0.85 & 13.54 & 2.57 & 3.44 & 0.38 & 1.53 & 1.07 \\
\hline n-Hexane & 1.42 & 3.12 & 0.12 & 3.57 & 0.04 & 0.60 & 0.13 & 0.15 \\
\hline 2,3-Dimethyllbutane & 4.81 & 3.89 & 0.56 & 0.56 & - & - & 0.01 & 1.83 \\
\hline 2-Methylhexane & - & 0.74 & 1.12 & 0.25 & - & - & 0.74 & 0.25 \\
\hline 3-Ethylpentane & - & - & - & - & - & - & - & - \\
\hline 3-Methylhexane & - & - & - & - & - & - & 0.46 & 0.55 \\
\hline
\end{tabular}


Table 3

CONTINUATED

\begin{tabular}{|c|c|c|c|c|c|c|c|c|}
\hline $\mathbf{2 , 2 , 3 - T r i m e t h y l b u t a n e ~}$ & - & - & - & 0.34 & 0.29 & - & 0.08 & 0.82 \\
\hline Methylcyclohexane & 2.05 & - & - & 0.32 & - & - & 1.19 & 0.31 \\
\hline n-Heptane & - & - & - & 0.10 & - & - & - & 0.31 \\
\hline Benzene & - & - & - & 29.26 & - & - & - & 2.95 \\
\hline i-Octane & - & - & - & - & - & - & - & 0.45 \\
\hline n-Octane & - & - & - & 0.02 & - & - & - & 0.03 \\
\hline Toluene & - & - & - & 2.26 & - & - & - & 0.29 \\
\hline Styrene & - & - & - & 36.15 & - & - & - & 40.01 \\
\hline Hydrogen & 2.19 & 4.59 & 0.96 & 2.23 & 3.76 & 3.63 & 1.37 & 2.49 \\
\hline Carbon monoxide & 0.65 & 0.72 & 0.85 & 0.93 & 0.94 & 2.33 & 1.20 & 0.61 \\
\hline Carbon dioxide & 4.17 & 1.28 & 0.99 & 0.44 & 2.80 & 1.24 & 1.41 & 0.43 \\
\hline
\end{tabular}

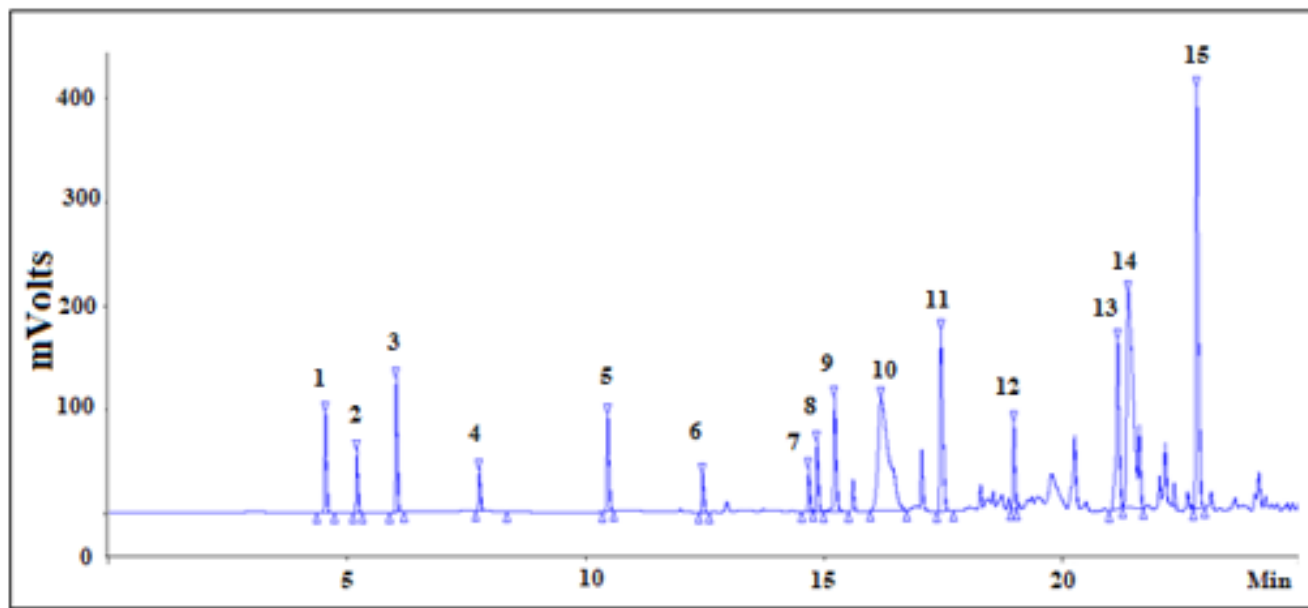

1-Methane

2-Ethylene

5-Propylene

6 - $i$-Butane

7-n-Butane

$7-n-B u t a n e$
$8-n e a-P e n t a n e$

9-i-Pentane

10 - n-Pertane

$11-n-$ Hexane

12-2,3-dimethybutane

13-2-Methyllevane

14-Toluese

15 - Strrene

Fig. 4. Typical GC-FID chromatogram for the gas derived from PS pyrolysis

\begin{tabular}{|c|c|c|}
\hline Feed material & HHV, at 0 ${ }^{\circ} \mathbf{C}$ (MJ/kg) & EF (t/TJ) \\
\hline HDPE & 99.83 & 69.44 \\
\hline LDPE & 99.46 & 69.62 \\
\hline PP & 105.04 & 70.11 \\
\hline PS & 121.18 & 95.53 \\
\hline HDPE / Zeolite & 92.09 & 70.19 \\
\hline LDPE / Zeolite & 93.03 & 69.69 \\
\hline PP / Zeolite & 100.77 & 70.39 \\
\hline PS / Zeolite & 105.01 & 112.23 \\
\hline HDPE / Lignite & 73.42 & 83.59 \\
\hline LDPE / Lignite & 92.57 & 70.02 \\
\hline PP / Lignite & 92.64 & 68.66 \\
\hline PS / Lignite & 76.46 & 123.71 \\
\hline
\end{tabular}

Table 4

HIGHER HEATING VALUE AND EMISSION FACTOR OF DERIVED GAS FROM PYROLYSIS PLASTIC

The HHV for the resulted oils varied in the 40.17-45.35

\section{Conclusions}

This study evaluated the pyrolysis process of various plastics in the presence of zeolite or lignite as catalysts, in terms of product yields and composition, higher heating values and emission factors.

The results shown that the introduction of zeolite in the pyrolysis processes affected the oil fraction by decreasing it. The lowest oil fraction was obtained for LDPE pyrolysis in the zeolite presence (38\%) and the highest oil fraction was obtained from PS pyrolysis in the presence of lignite (79\%).

Significant contents of aromatic compounds were found in the oil produced from PS with and without catalyst, due to its high stability. The highest ratio of aromatics was observed in the oil resulted from PS pyrolysis in the presence of lignite ( $\sim 5 \%)$.

The low sulphur content (under the European legislation limit for diesel fuels) make the pyrolysis oil an environmentally friendly alternative for conventional fuels.
$\mathrm{MJ} / \mathrm{kg}$ range. Furthermore, the derived gases presented also significant heat values, between $73.42-121.18 \mathrm{MJ} / \mathrm{m}^{3}$.

Acknowledgments: The work has been funded by the Romanian Ministry of Scientific Research and Innovation, PN-III-CERC-CO-Cl2018 Program, under Project no. 159CI/2018 Plastic wastes as vector for energy -ENERGPLAS"

\section{References}

1. WONG S.L., NGADI N., ABDULLAH T.A.T., INUWA I.M., Renewable and Sustainable Energy Reviews, 50, 2015, p.1167.

2. *** Association of Plastic Manufacturers Europe, Plastic - the facts 2017. An analysis of European plastics production, demand and waste data. Belgium: European Association of Plastics Recycling and Recovery Organisations, 2017, p. 1-44.

3. SHARUDDIN S.D.A., ABNISA F., DAUD W.M.A., Energy Conversion and Management, 115, 2016, p. 308.

4. CONESA J.A., FONT R., MARCILLA A., GARCIA A.N., Energy Fuel, 8, 1994, p.1238.

5. WALLIS M.D., BHATIA S.K., Polym Degrad Stab, 92, no. 9, 2007, p. 1721. 
6. PANDA A.K., SINGH R.K., J Fuel Chem Technol, 39, no. 3, 2011, p. 198.

7. PARK J.W., KIM J.H., SEO G., Polym Degrad Stab, 76, no. 3, 2002, p. 495.

8. LOPEZ A., MARCO I., CABALLERO B.M., LARESGOITI M.F., ADRADOS A., Chemical Engineering J ournal, 173, 2011, p. 62. 9. DAS P., TIWARI P., Resources, Conservation \& Recycling, 128, 2018, p. 69.

10. JOHANSSON A.C., SANDSTROM L., OHRMAN O.G.W., JILVERO H., J ournal of Analytical and Applied Pyrolysis, 134, 2018, p. 102.

11. LIN X., ZHANG Z., ZHANG Z., SUN J., WANG Q., PITTMAN C.U., Waste Management, 79, 2018, p. 38.

12. *** The University of York. Chemical reactors. The Essential Chemical Industry [online]. UK: The University of York; 2013.

13. ELORDI G., OLAZAR M., AGUADO R., LOPEZ G., ARABIOURRUTIA M., BILBAO J., J Anal Appl Pyrol, 79, 2007, p. 450.

14. DOBRE TANASE, PARVULESCU O.A., RAMOS I.R., CEATRA L., STROESCU M., STOICA A., MIREA R., Rev. Chim. (Bucharest), 63, no.1, 2012, p. 54.

15. PARVULESCU O.A., GAVRILA A.I., DOBRE T., CEATRA L., Rev. Chim. (Bucharest), 67, no.11, 2016, p. 2254.

16. KALARGARIS I., TIAN G., GU S., Energy, 131, 2017, 179.

17. TILL Z., VARGA T., SOJA J., MISKOLCZI N., CHOVAN T., 173, 2018, p. 320.

18.MIANDAD R., REHAN M., NIZAMI A-S., EL-FETOUH BARAKAT M.A., ISMAIL I.M, Recycl. Solid Waste Biofuels Bio-Chem Singapore: Springer Singapore, 2016, p. 333.
19. WANG J.L., WANG L.L., Energy Sources, Part A: Recovery, Utilization, and Environmental Effects, 33, 2011, p. 1940.

20. MIGUEL G.S., SERRANO D.P., AGUADO J., Industrial \& Engineering Chemistry Research, 48, 2009, p. 8697.

21. SYAMSIRO M., SAPTOADI H., NORSUJ IANTO T., NOVIASRI P., CHENG

S., ALIMUDDIN Z., YOSHIKAWA K., Energy Procedia, 47, 2014, p. 180.

22. BUCURA F., IONETE R.E., MARIN F., MIRICIOIU M., SAROS G., ZAHARIOIU A., CONSTANTINESCU M., Progress of Cryogenics and Isotopes Separation, 21, Issue 1, 2018, p. 97.

23. STEGARUSD., NICULESCU V., GEORGESCU C., IANCU R., LENGYEL E., TITA O., Revue Roumaine de Chimie, 60, 2015, p. 507.

24.*** ASTM International. ASTM D240 - 17. Standard Test Method for Heat of Combustion of Liquid Hydrocarbon Fuels by Bomb Calorimeter 25.*** ASTM International. ASTM D5291-16 Standard Test Methods for Instrumental Determination of Carbon, Hydrogen, and Nitrogen in Petroleum Products and Lubricants

26. *** IPCC 2008, 2006 IPCC Guidelines for National Greenhouse Gas Inventories-A primer, Prepared by the National Greenhouse Gas Inventories Programme, Eggleston H.S., Miwa K., Srivastava N. and Tanabe K. (eds). Published: IGES, Japan.

27. *** International Organization for Standardization. ISO 6976:2016. Natural gas-Calculation of calorific values, density, relative density and Wobbe indices from composition.

Manuscript received: 3.12 .2018 